\title{
The antidiabetic drug lobeglitazone has the potential to inhibit PTP1B activity
}

Ruth F. Rocha ${ }^{a}$, Tiago Rodrigues ${ }^{\mathrm{c}}$, Angela C. O. Menegattia, ${ }^{\mathrm{a} *}$, Gonçalo J. L. Bernardes $^{\mathrm{c}, \mathrm{d}^{*}}$, HernánTerenzi $\mathrm{i}^{\mathrm{a}}$

5

${ }^{a}$ Centro de Biologia Molecular Estrutural, Departamento de Bioquímica, Universidade Federal de Santa Catarina, Campus Trindade, 88040-900, Florianópolis, SC, Brazil

${ }^{b}$ Universidade Federal do Piauí, CPCE, 64900-000, Bom Jesus, PI, Brazil

${ }^{c}$ Instituto de Medicina Molecular, Faculdade de Medicina, Universidade de Lisboa, Avenida Professor Egas Moniz, 1649-028 Lisbon, Portugal

${ }^{d}$ Departmentof Chemistry, University of Cambridge, Lensfield Road, CB2 1EW, Cambridge, $U K$

\section{Abstract}

Protein tyrosine phosphatase 1B (PTP1B) is considered a potential therapeutic target for the treatment of type 2 diabetes mellitus (T2DM), since this enzyme plays a significant role to down-regulate insulin and leptin signalling and its over expression has been implicated in the development of insulin resistance, T2DM and obesity. Some thiazolidinediones (TZD) derivatives have been reported as promising PTP1B inhibitors with anti hyperglycemic effects. Recently, lobeglitazone, a new TZD, was described as an antidiabetic drug that targets the PPAR- $\gamma$ (peroxisome $\gamma$ proliferatoractivated receptor) pathway, but no information on its effects on PTP1B have been reported to date. We investigated the effects of lobeglitazone on PTP1B activity in vitro. Surprisingly, lobeglitazone led to moderate inhibition on PTP1B $\left(\mathrm{IC}_{50} 42.8 \pm 3.8 \mu \mathrm{M}\right)$ activity and to a non-competitive reversible mechanism of action. As lobeglitazone inhibits PTP1B activity in vitro, we speculate that it could also target PTP1B signalling pathway in vivo and thus contribute to potentiate its antidiabetic effects.

Keywords: Thiazolidinediones; lobeglitazone; PPAR- $\gamma$; PTP1B; Non-competitive inhibitors.

*e-mail id : angelamenegatti@yahoo.com.br;gb453@cam.ac.uk 


\section{Introduction}

Protein tyrosine phosphatases (PTPs) as potential therapeutic targets have been an important topic in biomedical science for the last two decades, because a large number of PTPs dysfunctions are associated with several human diseases, such as cancer, diabetes, autoimmune and neurological diseases [1-6]. Several years of study revealed that protein tyrosine phosphatase 1B (PTP1B), which is a negative regulator of insulin and leptin signalling pathway [5-14], plays an important role in the development of many diseases, including diabetes and obesity. Knockout studies in mice models show that animals that do not express PTP1B present insulin hypersensitivity and low blood glucose levels $[14,15]$. Furthermore, the gene encoding PTP1B is located in chromosome 20q13, a genomic region associated with type 2 diabetes mellitus (T2DM) [16]. Also, PTP1B overexpression contributes to the development of insulin resistance, T2DM and obesity [17]. Insulin exerts its effects when it binds to insulin receptor protein tyrosine kinase, which initiates signalling pathways, particularly those that induce phosphorylation. Diabetes is a disease, related to insulin resistance, in which signalling responses to hormones are attenuated [18]. According to Krishnan et al. an ideal therapeutic target would be one that functions as a negative regulator of both signalling pathways, where their inhibition would restore a normal hormonal response [19].

PTP1B is one such target that counteracts tyrosine phosphorylation events by promoting insulin signalling and simultaneously interrupts glycaemic control. Hence, PTP1B inhibition has been validated as a potentialtherapeutic strategy to enhance insulin sensitivity, and inhibitors of this enzyme are being suggested as potent antidiabetic drugs [20]. Numerous PTP1B inhibitors have been reported so far, including natural products, synthetic heterocyclic or hybrid compounds, but only a few have reached clinical trials. However, none of them have reached the market yet [21].

There are currently several treatment options available to control T2DM, in particular antidiabetic agents that act as hypoglycemic drugs, such as thiazolidinediones (TZDs), which are synthetic peroxisome $\gamma$ proliferator-activated receptor (PPAR- $\gamma$ ) agonists [22-24]. Activation of PPAR- $\gamma$ increases glucose uptake and use in peripheral organs, in addition to fatty acid storage in adipocytes, insulin signalling and decreases 
liver gluconeogenesis, thereby improving insulin sensitivity [22, 25, 26]. TZDs also affect a range of activities, including cell proliferation, apoptosis, inflammation, and responses to oxidative stress [27, 28]. Although effective, TZDs, such as rosiglitazone and pioglitazone, are associated with weight gain, increased risk of heart failure, and bladder cancer among others [29-31].

Recently, a new PPAR- $\gamma$ agonist was developed with a TZD moiety and substituted pyrimidines, lobeglitazone (Duvie ${ }^{\circledR}$; Fig. 1) is structurally similar to rosiglitazone and pioglitazone, two well-known TZD drugs [32-37]. Phase III trials have shown that glycated haemoglobin levels were decreased by $0.44 \%$ following lobeglitazone alone and by $0.74 \%$ as a complement to metformin therapy. This drug was approved by the Ministry of Food and Pharmaceutical Safety (Korea) in 2013 and has since been used as a daily treatment of T2DM $[38,39]$. As PTP1B inhibition improves the sensitivity to insulin and some TZD analogues have been reported as PTP1B inhibitors [40-46], we sought to determine the effect of lobeglitazone on PTP1B activity in vitro. Lobeglitazone is used as an antidiabetic drug that targets PPAR- $\gamma$ pathway, but no information regarding its effects on PTP1B is reported.<smiles>COc1ccc(Oc2cc(N(C)CCOc3ccc(CC4SC(=O)NC4=O)cc3)ncn2)cc1</smiles>

Fig. 1. Structure of Lobeglitazone.

\section{Results and Discussion}

Initially, in vitro inhibitory activity of lobeglitazoneagainstPTP1Bwas assessed spectrophotometrically at $40 \mu \mathrm{M}$ using $p$ NPP as substrate. Lobeglitazone reduced 41.5 $\pm 2.7 \%$ of enzymatic activity with an $\mathrm{IC}_{50}$ value of $42.8 \pm 3.8 \mu \mathrm{M}$, which means it is a moderate inhibitor of PTP1B.

Several TZD derivatives have been reported as PTP1B inhibitors with antihyperglycemic and antiobesity effects [40-46]. Liu et al. discovered and optimized 
a series of new PTP1B inhibitors that contain TZD-substituted biphenyl scaffold and further evaluated the inhibitory effects of these compounds in vitro and in vivo [45]. Among them, compound (Z)-5-((4'-(benzyloxy)biphenyl-4-yl)methylene)-2thioxothiazolidin4-one $(7 \mathrm{Fb})$, derived from 4 oxothiazolidine-2-thione, exhibited an $\mathrm{IC}_{50}$ value of $0.69 \pm 0.07 \mu \mathrm{M}$ for PTP1B. The compound significantly decreased postprandial and fasting glucose levels, and blood glucose levels decreased more rapidly than in mice treated with metformin, which demonstrates its potency as an antidiabetic agent. A number of new 5-benzene lidene-2,4-thiazolidinedione derivatives have been designed and synthesized by Wang et al. based on their previous studies [46]. Compound (Z)-5-(5-bromo-4-((3-methylbut-2-en-1-yl) oxy)-2methoxybenzylidene)-3-isopropylthiazolidine-2, 4-dione (7e) exhibited potent competitive inhibition of PTP1B, with an $\mathrm{IC}_{50}$ value of $4.6 \mu \mathrm{M}$. Although lobeglitazone seems to have moderate activity against PTP1B, comparing its potency with other inhibitor described for this enzyme, we cannot exclude that it might have some inhibitory activity of PTP1B in vivo, since Mahapatra et al. reported two TZD derivatives with $\mathrm{IC}_{50}$ values of $\approx 7.5 \mu \mathrm{M}$ that significantly reduced the blood sugar level in vivo relative to standard drug pioglitazone.

Based on the $\mathrm{IC}_{50}$ value, we investigated the mode of inhibition of lobeglitazone by evaluating the PTP1B kinetic parameters. Kinetic analysis revealed that lobeglitazone is a non-competitive inhibitor $(\alpha=1)$ of PTP1B (Fig. 2), with a $K_{i}$ value of $61.0 \pm 9.0$ $\mu \mathrm{M}$.

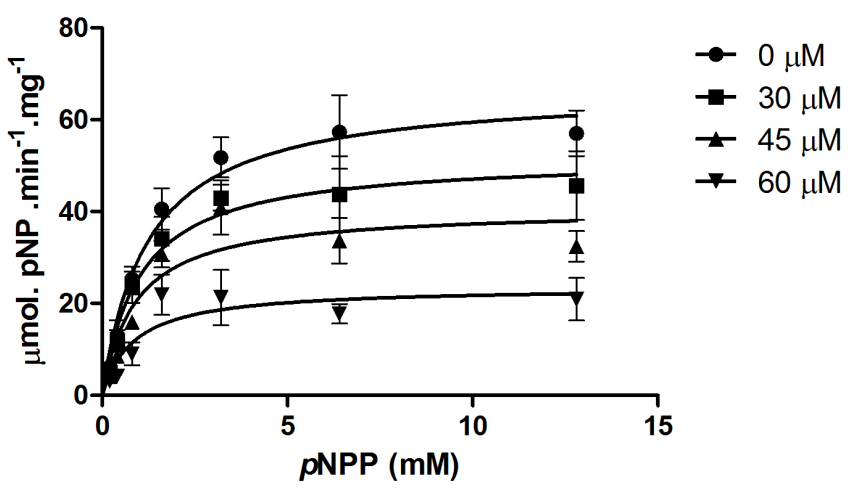


Fig. 2.Michaelis-Menten chart that represents the inhibition mechanism for lobeglitazone against PTP1B.

The finding that lobeglitazone has a non-competitive mechanism of inhibition may represent an important feature because this of type inhibition has demonstrated potential to lead to selectivity and potency. Recently, research has advanced towards the development allosteric inhibitors of PTPs. Trodusquemine (MSI-1436) a reversible non-competitive allosteric inhibitor of PTP1B attenuates its ability to promote HER2dependent tumorigenesis in vivo and reached phase I clinical trials for breast cancer and phase 2 clinical trials for T2DM [48]. This promising PTP1B allosteric inhibitor has boosted research in the field of PTP-based drug discovery [49]. Thus highlighting the importance of the search for non-competitive inhibitors of these enzymes, mainly because their active sites are well conserved among the family [50, 51].

Besides, different types of inhibitions are described for TZD inhibitors of PTP1B, which includes non-competitive mechanisms, but all the reports indicate reversible inhibition $[41-43,47]$. Thus, to determine whether the inhibition was caused by the formation of a reversible or irreversible enzyme-inhibitor complex, we investigated the recovery of the phosphatase activity by a pre-incubation and dilution assay [52]. The results demonstrated that the recovery of activity for lobeglitazone was $93.0 \pm 5.0 \%$, which means it behaves as a reversible inhibitor of PTP1B (Fig. 3). This also potentially excludes the formation of colloidal aggregates by lobeglitazone that could lead to local enzyme denaturation and false positive readouts [62]. 


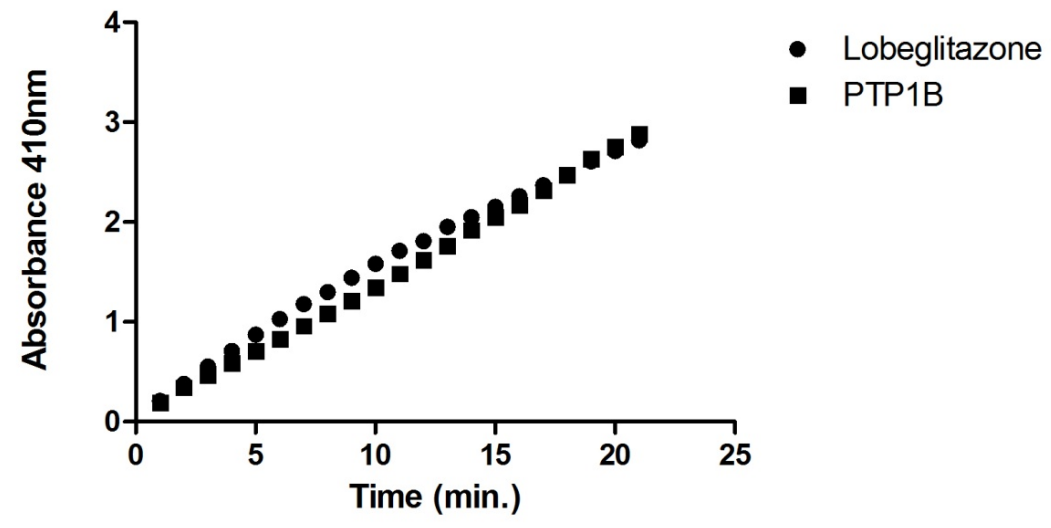

Fig. 3. Reversibility of PTP1B inhibition by lobeglitazone. Representative graph of three independent experiments.

To corroborate the results of the kinetic analysis, we conducted a limited proteolysis assay to understand the availability of the active site of the enzyme for proteolysis. First, we analyzed the PTP1B peptide mass fingerprint (PMF) in the presence and absence of lobeglitazone. Approximately $86.3 \%$ of the PTP1B sequence was covered in the PMF analysis in the presence and $76.3 \%$ in the absence of lobeglitazone. By comparing the PMF spectra, we observed that peptides of the PTP1B active site were not protected by the presence of the compound, the peaks 2175 and $2430 \mathrm{~m} / z$ (Fig. S1 and S2 Supplementary material) remain the same, which confirms that lobeglitazone is a non-competitive inhibitor, however further studies are needed to determine the binding site of this inhibitor on the enzyme.

Our results reveal that lobeglitazone has an inhibitory activity of PTP1B in vitro, thus despite its weaker PTP1B activity, this partial inhibition could contribute positively to the effects observed with its primary target PPAR- $\gamma$. Some studies have shown the effect of insulin sensitization due to the combination of activating PPAR- $\gamma$ and inhibiting PTP1B activity [43, 44, 53, 54]. Kubo et al. compare the pharmacological profile of two PPAR- $\gamma$ agonists, the KY201 (EC50: $287 \pm 88 \mathrm{nM}$ ) and rosiglitazone $\left(\mathrm{EC}_{50}: 148 \pm 39 \mathrm{nM}\right)$ in ovariectomized rats [53]. KY201, but not rosiglitazone, inhibited PTP1B ( $\left.\mathrm{IC}_{50}: 3.7 \pm 1 \mu \mathrm{M}\right)$ and increased insulin receptor phosphorylation in HepG2 cells. These results suggest that the effects of KY201 are similar to those of 
rosiglitazone, but with less adverse effects due to the combination of partial PPAR- $\gamma$ activation and PTP1B inhibition. Bhattarai et al. also reported the efficacy of new TZD derivatives with dual action as PTP1B inhibitors and PPAR- $\gamma$ activators, to suppress weight gain and improve blood parameters [44].

Current studies continue to demonstrate the importance of PTP1B inhibition as a potential target for the treatment of T2DM [6,55-57]. Ottanà et al. designed and evaluated 3-aryl-5-arylidene-2-thioxo-4-imidazolidinones as a new class of noncarboxylated PTP1B inhibitors that act as reversible non-competitive inhibitors and as potent insulin-sensitizing agents [55]. Their results demonstrate that these noncompetitive PTP1B inhibitors can be considered promising compounds to improve the druggability of the target enzyme. Recently, Liu et al. designed and synthesized 17 new 4-thiazolinone derivatives as new PTP1B inhibitors for the treatment of T2DM [6].

\section{Conclusions}

In conclusion, we showed that the potent PPAR- $\gamma$ agonist lobeglitazone is a PTP1B inhibitor in vitro, with an $\mathrm{IC}_{50}$ and $K_{\mathrm{i}}$ values of $42.8 \pm 3.8 \mu \mathrm{M}$ and $61.0 \pm 9.0$ $\mu \mathrm{M}$, respectively. Furthermore, lobeglitazone presented a reversible non-competitivetype inhibition against PTP1B. This finding suggests that lobeglitazone might have potential to inhibit PTP1B in vivo, as has been shown for other PPAR- $\gamma$ agonists. Thus, this partial inhibition could have a positive off-target effect on lobeglitazone treatment, complementing PPAR- $\gamma$ activation. Consequently, these results may stimulate further understanding of current treatments for T2DM with lobeglitazone, lead to the development of new strategies with multiple mechanisms of action and lobeglitazone could be a lead compound for the development of potent PTP1B inhibitor drugs. 


\section{Materials and Methods}

\subsection{Expression and purification of recombinant human PTP1B}

To perform PTP1B expression and purification, the protocol previously described by Brandão et al. was used [58]. After purification, the protein was concentrated by ultrafiltration with a $30 \mathrm{kDa}$ pore membrane (Amicon Ultra-15 Millipore). The final protein concentration was determined by Bradford assay [59].

\subsection{Biochemical evaluation}

PTP1B phosphatase activity was tested by using $p$ NPP as substrate. Firstly, the recombinant protein $(38 \mathrm{nM})$ was incubated at $37^{\circ} \mathrm{C}$ for $10 \mathrm{~min}$ in imidazole buffer (20 mM), pH 7.0, using eleven different concentrations of lobeglitazone $(40 \mu \mathrm{M}$ dissolved in DMSO) at $4 \%$ DMSO. The reaction was initiated by adding $p$ NPP $(5 \mathrm{mM})$, the quantity of $p$-nitrophenol produced was monitored spectrophotometrically at 410 $\mathrm{nm}$ for $10 \mathrm{~min}$. Analysis of the enzymatic activity was carried out in 96-well plates and the absorbance was measured on an ELISA plate spectrophotometer (Multiskan FC). The enzyme with DMSO (4\%) was considered as positive control and the absence of enzyme was the negative control. The enzymatic activity was expressed in \% of phosphatase residual activity relative to wells without inhibitor. All assays were done in triplicate in at least three independent experiments. $\mathrm{The} \mathrm{IC}_{50}$ values were determined by increasing concentrations of inhibitor $(1$ e $100 \mu \mathrm{M})$ versus $\%$ of inhibition, in triplicate in at least three independent experiments. The experimental data was analysed with GraphPad Prism 5.0 (GraphPad Software, La Jolla, CA) and the $\mathrm{IC}_{50}$ values determined by linear regression.

\subsection{Kinetic measurements}

To determine the kinetic parameters and the mechanism of inhibition, three concentrations of the compound, by using the $\mathrm{IC}_{50}$ value as reference, and seven $p$ NPP concentrations were used $(0.2,0.4,0.8,1.6,3.2,6.4$ and $12.8 \mathrm{mM}) . V_{\max }$ and $K_{\text {mapp }}$ values were determined for each compound concentration by nonlinear adjustment of the 
Michaelis-Menten equation data. Kinetic parameters and inhibition constant $\left(K_{i}\right)$ were determined by nonlinear regression of the data according to the specific equation for each inhibition mode. All data were generated and plotted by using the GraphPad Prism 5.0 software (GraphPad Software, La Jolla, CA). All assays were done in triplicate in at least three independent experiments.

\subsection{Enzyme Activity Reversibility Assay}

Recovery of enzymatic activity was determined after a large and rapid dilution of the enzyme inhibitor complex [61]. Control (enzyme in 10\% DMSO) and inhibition reactions (lobeglitazone at 10 fold $\mathrm{IC}_{50}$ value) were previously incubated in imidazole (20 mM, pH 7.0) for 30 minutes at $37^{\circ} \mathrm{C}$. Afterwards, $2 \mu \mathrm{L}$ of this mixture was diluted 100 -fold in a solution with imidazole $(20 \mathrm{mM})$ and $\rho \mathrm{NPP}(10 \mathrm{mM})$. The amount of $p \mathrm{NP}$ produced was measured at $410 \mathrm{~nm}$ for $20 \mathrm{~min}$ (with readings every minute) at $37^{\circ} \mathrm{C}$. All assays were performed in triplicate.

\subsection{Limited Proteolysis of Enzyme-Inhibitor Complex}

A proteolysis assay of the enzyme inhibitor complex was performed by using trypsin protease (Trypsin Gold, Mass Spectrometry Grade, Promega). In this analysis, PTP1B at a final concentration of $5 \mu \mathrm{M}$ was incubated with lobeglitazone at a final concentration of $100 \mu \mathrm{M}$ at $4 \%$ DMSO or with $4 \%$ DMSO in a $25 \mathrm{mM}$ ammonium bicarbonate solution $\mathrm{pH} 7.5$ for 10 minutes at $37{ }^{\circ} \mathrm{C}$. After this period, protease was added $(10 \mu \mathrm{g} / \mathrm{ml}$ with a protease-protein ratio of 1:50). The digestion reaction was incubated at $37^{\circ} \mathrm{C}$ for $1 \mathrm{~h}$. Then, $1 \mu \mathrm{L}$ aliquots of the reaction was transferred to a microtube that contained $3 \mu \mathrm{L}$ of the saturated solution of the alpha-cyano-4hydroxycinnamic acid matrix ( $5 \mathrm{mg} / 50 \%$ acetonitrile, $0.1 \%$ trifluoroacetic acid). Then $1 \mu \mathrm{L}$ of this mixture was applied directly to the MALDI-TOF/TOF Autoflex III Smartbean (Bruker Daltonics) spectrometer plate and crystallized at room temperature. After crystallization of the sample, mass spectrometry analysis was performed in positive mode. The spectra were analysed by using the Flex Analysis 3.3 program. The PMF profile obtained by MS was identified by comparison with the theoretical 

Daltonics). All assays were performed in triplicate [62].

\section{Acknowledgements}

The authors would like to thank the following facilities for their contributions to this work, the Instituto de Medicina Molecular (iMM), Faculdade de Medicina, Universidade de Lisboa (ULisboa), Central Laboratory of Structural Biology of the Federal University of Santa Catarina (UFSC). We gratefully acknowledge financial support from CNPq and CAPES (Brazil). The authors thank Dr Vikki Cantrill for her help with the editing of this manuscript.

\section{References}

[1] R.-J. He, Z.-H. Yu, R.-Y. Zhang, Z.-Y. Zhang, Protein tyrosine phosphatases as potential therapeutic targets, ActaPharmacol Sin. 35 (2014) 1227-1246, https://doi.org/10.1038/aps.2014.80.

[2] R. He, L.-F. Zeng, Y. He, S. Zhang, a Z.-Y. Zhang, Small molecule tools for functional interrogation of protein tyrosine phosphatases, FEBS J. 280 (2013) 731-750, https://doi.org/10.1111/j.1742-4658.2012.08718.x.

[3] S.G. Julien, N. Dube, S. Hardy, M.L. Tremblay, Inside the human cancer tyrosine phosphatome, Nat Rev Cancer. 11 (2011) 35-49, https://doi.org/10.1038/nrc2980.

[4] A. Mascarello, A.C.O. Menegatti, A. Calcaterra, P.G. A. Martins, L.D. Chiaradia-Delatorre, I. D'Acquarica, F. Ferrari, V. Pau, A. Sanna, A. De Logu, M. Botta, B. Botta, H. Terenzi, M. Mori, Naturally occurring Diels-Alder-type adducts from Morusnigra as potent inhibitors of Mycobacterium tuberculosis protein tyrosine phosphatase B, Eur J Med Chem. 144 (2017) 277-288, https://doi.org/10.1016/j.ejmech.2017.11.087. 
[5] N.K. Tonks, Protein Tyrosine Phosphatases: From Housekeeping Enzymes to Master-Regulators of Signal Transduction, FEBS J. 280 (2013) 346-378, https://doi.org/10.1111/febs.12077.

[6] W.-S. Liu, R.-R. Wang, H. Yue, Z.-H. Zheng, X.-H. Lu, S.-Q. Wang, W.-L. Dong, R.-L. Wang, Design, synthesis, biological evaluation and molecular dynamics studies of 4-thiazolinone derivatives as protein tyrosine phosphatase 1B (PTP1B) inhibitors, JBiomol Struct Dyn.19 (2019) 1-11, https://doi.org/10.1080/07391102.2019.1664333.

[7] M. Feldhammer, N. Uetani, D. Miranda-Saavedra, M.L. Tremblay, PTP1B: a simple enzyme for a complex world, Crit. Rev Biochem Mol Biol. 48 (2013) 430-445, https://doi.org/10.3109/10409238.2013.819830.

[8] B.L. Seely, P.A. Staubs, D.R. Reichart, P. Berhanu, K. L. Milarski, A.R. Saltiel, J. Kusari, J.M. Olefsky, Protein tyrosine phosphatase 1B interacts with the activated insulin receptor, Diabetes. 45(1996)1379-1385, https://doi.org/10.2337/diab.45.10.1379.

[9] K.A. Kenner, E. Anyanwu, J. M. Olefsky, J. Kusari, Protein-tyrosine phosphatase 1B is a negative regulator of insulin- and insulin-like growth factor-I-stimulated signaling, J. Biol. Chem. 271 (1996) 19810-19816, https://doi.org/10.1074/jbc.271.33.1981.

[10]H. Cho, Protein tyrosine phosphatase 1B (PTP1B) and obesity, VitamHorm. 91 (2013) 405-24, https://doi.org/10.1016/B978-0-12-4077669.00017-1.

[11]B.T. Zhao, D.H. Nguyen, D.D. Le, J.S. Choi,B.S. Min, M.H. Woo, Protein tyrosine phosphatase 1B inhibitors from natural sources, Arch Pharm Res.41 (2017) 130-161, https://doi.org/10.1007/s12272-017-0997-8.

[12] S.K. Baskaran, N. Goswami, S. Selvaraj, V.S. Muthusamy, B.S. Lakshmi, Molecular dynamics approach to probe the allosteric inhibition of PTP1B by chlorogenic and cichoricacid, J Chem Inf Model. 52 (2004) 2004-12, https://doi.org/10.1021/ci200581g.

[13] T.O. Johnson, J. Ermolieff, M.R. Jirousek, Protein tyrosine phosphatase 1B inhibitors for diabetes, Nat Rev Drug Discov. 1 (2002) 696-709, https://doi.org/10.1038/nrd895. 
[14] M. Elchebly, P. Payette, E. Michaliszyn, W. Cromlish, S. Collins, A.L. Loy, D. Normandin, A. Cheng, J. Himms-Hagen, C.C. Chan, C. Ramachandran, M.J. Gresser, M.L. Tremblay, B.P. Kennedy, Increased insulin sensitivity and obesity resistance in mice lacking the protein tyrosine phosphatase-1B gene, Science $283 \quad$ (1999) 1544-1548, https://doi.org/10.1126/science.283.5407.1544.

[15] L.D. Klaman, O. Boss, O.D. Peroni, J.K. Kim, Martino, J.M. Zabolotny, N. Moghal, M. Lubkin, Y.B. Kim, A.H. Sharpe, A. Stricker-Krongrad, G.I. Shulman, B.G. Neel, B.B. Kahn, Increased energy expenditure, decreased adiposity, and tissue-specific insulin sensitivity in protein-tyrosine phosphatase 1B-deficient mice, Mol. Cell. Biol. 20 (2000) 5479-5489, https://doi.org/10.1128/MCB.20.15.5479-5489.2000.

[16] R.C. Tsou, K.K. Bence, The genetics of PTPN1 and obesity: insights from mouse models of tissue-specific PTP1B deficiency, J. Obes. (2012) 926857, https://doi.org/10.1155/2012/926857.

[17]B.J. Goldstein, A. Bittner-Kowalczyk, M.F. White, M. Harbeck, Tyrosine Dephosphorylation and Deactivation of Insulin Receptor Substrate-1 by Protein-tyrosine Phosphatase 1B, J Biol Chem. 275 (2000) 4283-4289, https://doi.org/10.1074/jbc.275.6.4283.

[18] T.O. Johnson, J. Ermolieff, M.R.Jirousek, Protein tyrosine phosphatase 1B inhibitors for diabetes, Nat. Rev. Drug Discov. 1 (2002) 696-709, https://doi.org/10.1038/nrd895.

[19] N. Krishnan, K.F. Konidaris, G. Gasser, N.K. Tonks, A potent, selective, and 320 orally bioavailable inhibitor of the protein-tyrosine phosphatase PTP1B improves insulin and leptin signalling in animal models, J Biol Chem. 293 (2018) 1517-1525, https://doi.org/10.1074/jbc.C117.819110.

[20] H. Hussain, I.R. Green, G. Abbas, S.M. Adekenov, W. Hussain, I. Ali,Protein tyrosine phosphatase 1B (PTP1B) inhibitors as potential anti-diabetes agents: patent review (2015-2018), Expert OpinTher Pat. 29 (2019) 689-702, https://doi.org/10.1080/13543776.2019.1655542. 
[21]J. Dowarah, V. P. Singh. Anti-diabetic drugs recent approaches and advancements, Bioorg. Med. Chem. 28 (2020) 115263, https://doi.org/10.1016/j.bmc.2019.115263.

[22] L. Han, W. J. Shen, S. Bittner, F. B. Kraemer, S.Azhar, PPARs: regulators of metabolism and as therapeutic targets in cardiovascular disease. Part I: PPARalpha, Future Cardiol. 13 (2017) 259-278, https://doi.org/10.2217/fca-2016$\underline{0059}$.

[23]H. Yki-Jarvinen, Thiazolidinediones, N Engl J Med. 351 (2004) 1106-1118, https://doi.org/doi:10.1056/NEJMra041001.

[24] G. Derosa, P. Maffioli, Peroxisome proliferator-activated receptor-gamma (PPAR-gamma) agonists on glycaemic control, lipid profile and cardiovascular risk, Curr Mol Pharmacol. 5 (2012) 272-281, https://doi.org/10.2174/1874467211205020272.

[25] D.L. Bain, A.F. Heneghan, K.D. Connaghan-Jones, M.T. Miura, Nuclear receptor structure: implications for function, Annu Rev Physiol.69 (2007) 201-220, https://doi.org/10.1146/annurev.physiol.69.031905.160308.

[26] J. Berger, D.E. Moller, The mechanisms of action of PPARs, Annu Rev Med. 53 (2002) 409-435, https://doi.org/10.1146/annurev.med.53.082901.104018.

[27] R. Cunard, M. Ricote, D. DiCampli, D.C. Archer, D.A. Kahn, C.K. Glas, C.J. Kelly, Regulation of cytokine expression by ligands of peroxisome proliferator activated receptors, J Immunol. 168 (2002) 2795-2802, https://doi.org/10.4049/jimmunol.168.6.2795.

[28] Y. Guan, Y. Zhang, M.D. Breyer, The role of PPARs in the transcriptional control of cellular processes, Drug News Perspect. 15 (2002) 147-154, https://doi.org/10.1358/dnp.2002.15.3.840011.

[29] C. Hampp, V. Borders-Hemphill, D.G.Moeny, D.K. Wysowski, Use of antidiabetic drugs in the U.S., 2003-2012, Diabetes Care. 37 (2014)13671374, https://doi.org/10.2337/dc13-2289.

[30] S.E. Nissen, K. Wolski, Rosiglitazone revisited: an updated meta-analysis of risk for myocardial infarction and cardiovascular mortality, Arch Intern Med. 170 (2010) 1191-1201, https://doi.org/10.1001/archinternmed.2010.207. 
[31] M. Ahmadian, J.M. Suh, N. Hah, C. Liddle, A.R. Atkins, M. Downes, R.M. Evans, PPAR gamma signalling and metabolism: the good, the bad and the future, Nat Med. 19 (2013) 557-566, https://doi.org/10.1038/nm.3159.

[32] J.Y. Jang, H. Bae, Y.J. Lee, Y. Il. Choi, H.-J. Kim, S.B. Park, S.W. Suh, S.W. Kim, B.W. Han, Structural Basis for the Enhanced Anti-Diabetic Efcacy of Lobeglitazone on PPAR $\gamma$, Sci Rep. 8, 31 (2018), https://doi.org/10.1038/s41598-017-18274-1.

[33] H.W. Lee,B.Y. Kim, J.B. Ahn, S.K.Kang, J. H.Lee, J. S. Shin, S. K. Ahn, S. J.Lee, S. S. Yoon, Molecular design, synthesis, and hypoglycaemic and hypolipidemic activities of novel pyrimidine derivatives having thiazolidinedione, Eur J Med Chem. 40 (2005) 862-874, https://doi.org/10.1016/j.ejmech.2005.03.019.

[34] J. W. Kim, J. R. Kim,S. Yi, K.H. Shin, H.S. Shin, S.H. Yoon, J.Y. Cho, D.H. Kim, S.G. Shin, I.J. Jang, K.S. Yu, Tolerability and pharmacokinetics of lobeglitazone (CKD501), a peroxisome proliferator-activated receptor-gamma agonist: a single- and multiple-dose, double-blind, randomized control study in healthy male Korean subjects, Clin Ther. 33 (2011) 1819-30, https://doi.org/10.1016/j.clinthera.2011.09.023.

[35] S.H. Kim, S.G. Kim, D.M. Kim, J.T. Woo, H.C. Jang, C.H. Chung, K.S. Ko, J.H. Park, Y.S. Park, S.J. Kim, D.S. Choi, Safety and efficacy of lobeglitazone monotherapy in patients with type 2 diabetes mellitus over 52 weeks: An open-label extension study, Diabetes Res Clin Pract. 110 (2015) 27-30, https://doi.org/10.1016/j.diabres.2015.09.009.

[36]H.S. Lee, M. Chang, J.E. Lee, W. Kim, I.C. Hwang, D.H. Kim, H.K. Park, H.J. Choi, W. Jo, S.W. Cha, W.C. Son, Carcinogenicity study of CKD501, a novel dual peroxisome proliferator-activated receptors alpha and gamma agonist, following oral administration to Sprague Dawley rats for 94101 weeks, Regul Toxicol Pharmacol. $69 \quad$ (2014) 207216, https://doi.org/10.1016/j.yrtph.2014.04.003.

[37] K.S. Moon, J.E. Lee, H.S. Lee, I.C. Hwang, D.H. Kim, H.K. Park, H.J. Choi, W. Jo, W.C. Son, H.I. Yun, CKD-501, a novel selective PPAR gamma agonist, shows no carcinogenic potential in ICR mice following oral 
administration for 104 weeks, J Appl Toxicol. 34 (2014) 12711284, https://doi.org/10.1002/jat.2918.

[38] S.G. Kim, D.M. Kim, J.T. Woo, H.C. Jang, C.H. Chung, K.S. Ko, J.H. Park, Y.S. Park, S. J. Kim, D.S. Choi, Efficacy and Safety of Lobeglitazone Monotherapy in Patients with Type 2 Diabetes Mellitus over 24-Weeks: A Multicenter, Randomized, Double-Blind, Parallel-Group, Placebo Controlled Trial, PLoS One. 9 2843, https://doi.org/10.1371/journal.pone.0092843.

[39] S.M. Jin, C.Y. Park, Y.M. Cho, B.J. Ku, C.W. Ahn, B.S. Cha, K.W. Min, Y.A. Sung, S.H. Baik, K.W. Lee, K.H. Yoon, M.K. Lee,S.W. Park,Lobeglitazone and pioglitazone as add-ons to metformin for patients with type 2 diabetes: a 24-week, multicentre, randomized, double-blind, parallelgroup, active-controlled, phase III clinical trial with a 28 -week extension, Diabetes Obes $\quad$ Metab. $17 \quad$ (2015) 602, https://doi.org/10.1111/dom.12435.

[40] M. K. Mahapatra, R. Kumar, M. Kumar, Synthesis, biological evaluation and in silico studies of 5-(3-methoxybenzylidene) thiazolidine-2,4-dione analogues as PTP1B inhibitors, Bioorg Chem. 71 (2017) 1-9, https://doi.org/10.1016/j.bioorg.2017.01.007.

[41] R. Ottanà, R. Maccari, R. Ciurleo, P. Paoli, M. Jacomelli, G. Manao, G. Camici, C.Laggner, T. Langer, 5-Arylidene-2-phenylimino-4-thiazolidinones as PTP1B and LMW-PTP inhibitors, Bioorg. Med. Chem. 17 (2009) 19281937, https://doi.org/10.1016/j.bmc.2009.01.044.

[42] R. Maccari, P. Paoli, R. Ottanà, M. Jacomelli, R. Ciurleo, G. Manao, T. Steindl, T. Langer, M.G. Vigorita, G. Camici, 5-Arylidene-2,4thiazolidinediones as inhibitors of protein tyrosine phosphatases, Bioorg. Med. Chem. 15 (2007) 5137 5149, https://doi.org/10.1016/j.bmc.2007.05.027.

[43] B.R. Bhattarai, B. Kafle, J.S. Hwang, D. Khadka, S.M. Lee, J.S. Kang, S.W. Ham, I.O. Han, H. Park, H. Cho, Thiazolidinedione derivatives as PTP1B inhibitors with antihyperglycemic and antiobesity effects, Bioorg. Med. Chem.

Lett.

19

(2009)

6161-6165, https://doi.org/10.1016/j.bmcl.2009.09.020. 
[44] B.R. Bhattarai, B. Kafle, J.S. Hwang, S.W. Ham, K.H. Lee, H. Park, I.O. Han, H. Cho, Novel thiazolidinedione derivatives with anti-obesity effects: Dual action as PTP1B inhibitors and PPAR-coactivators, Bioorg. Med. Chem. Lett. 20 (2010) 6758-6763, https://doi.org/10.1016/j.bmcl.2010.08.130.

[45]Z. Liu, Q. Chai, Y. Li, Q. Shen, L. Ma, L. Zhang, X. Wang, L. Sheng, J. Li, J. Li, J. Shen, Discovery of novel PTP1B inhibitors with antihyperglycemic activity, Acta Pharmacol. Sin. 31 (2010) 1005-1012, https://doi.org/10.1038/aps.2010.81.

[46]Z. Wang, Z. Liu, W. Lee, S.-N. Kim, G. Yoon, S.H. Cheon, Design, synthesis and docking study of 5-(substituted benzylidene)thiazolidine-2,4-dione derivatives as inhibitors of protein tyrosine phosphatase 1B, Bioorg. Med. Chem. Lett. 24 (2014) 3337-3340, https://doi.org/10.1016/j. bmcl.2014.05.099.

[47] R. Ottanà, R. Maccari, J. Mortier, A. Caselli, S. Amuso, G. Camici, A. Rotondo, Wolber, P. Paoli, Synthesis, biological activity and structure activity relationships of new benzoic acid-based protein tyrosine phosphatase inhibitors endowed with insulin mimetic effects in mouse $\mathrm{C} 2 \mathrm{C} 12$ skeletal muscle cells, Eur J Med Chem. 71 (2014) 112-127, https://doi.org/10.1016/j.ejmech.2013.11.001.

[48] D. Thompson, N. Morrice, L. Grant, S. Le Sommer, E. K. Lees, N. Mody, H. M. Wilson, M. Delibegovic, Pharmacological inhibition of protein tyrosine phosphatase $1 \mathrm{~B}$ protects against atherosclerotic plaque formation in the LDLR(-/-) mouse model of atherosclerosis, Clin Sci (Lond). 131 (1979) 24892501, https://doi.org/10.1042/CS20171066.

[49] N. Krishnan, K. F. Konidaris, G. Gasser, N. K. Tonks, A potent, selective, and orally bioavailable inhibitor of the protein-tyrosine phosphatase PTP1B improves insulin and leptin signalling in animal models, J Biol Chem.293 (2018)1517-1525, https://doi.org/10.1074/jbc.C117.819110. 22 (2017) 2269, https://doi.org/10.3390/molecules22122269. 
[51] Z.Y. ZHANG, Drugging the Undruggable: Therapeutic Potential of Targeting Protein Tyrosine Phosphatases, Acc Chem Res.50 (2017) 122-129, https://doi.org/10.1021/acs.accounts.6b00537.

[52] R.A. Copeland, Evaluation of enzyme inhibitors in drug discovery. A guide for medicinal chemists and pharmacologists, Methods Biochem Anal.46 (2005) 1-265, https://doi.org/10.1002/9781118540398.

[53] M. Kubo, M. Fukui, Y. Ito, T. Kitao, H. Shirahase, E.H.Y. Yoneda, Insulin Sensitization by a Novel Partial Peroxisome Proliferator-Activated Receptor g Agonist With Protein Tyrosine Phosphatase 1B Inhibitory Activity in Experimental Osteoporotic Rats, J Pharmacol Sci. (2014) 124276 - 285, https://doi.org/10.1254/jphs.13236fp.

[54] M.J. Nanjana, M. Mohammed, B.R.P. Kumar, M.J.N. Chandrasekar, Thiazolidinediones as antidiabetic agents: A critical review, Bioorg Chem.77 (2018) 548-567, https://doi.org/10.1016/j.bioorg.2018.02.009.

[55] R. Ottanà, P. Paoli, G. Lori, I. Adornato, S. Previti, A. Naß, G. Wolber, R. Maccari, Design and evaluation of non-carboxylate 5-arylidene-2-thioxo-4imidazolidinones as novel non-competitive inhibitors of protein tyrosine phosphatase 1B, Bioorg Chem. $92 \quad$ (2019) 10321, https://doi.org/10.1016/j.bioorg.2019.103211.

[56] K.P. Prabhakar, P. M. Sivakumar, Protein Tyrosine Phosphatase 1B Inhibitors: A Novel Therapeutic Strategy for the Management of Type 2 Diabetes Mellitus, Curr Pharm Des. $25 \quad$ (2019) 2526-2539, https://doi.org/10.2174/1381612825666190716102901.

[57] P. Eleftheriou, A. Geronikaki, A. Petrou, PTP1b Inhibition, A Promising Approach for the Treatment of Diabetes Type II, Curr Top Med Chem. 19 (2019) 246-263, https://doi.org/10.2174/1568026619666190201152153.

[58] T.A. Brandao, A.C. Hengge, S. J. Johnson, Insights into the reaction of protein-tyrosine phosphatase 1B: crystal structures for transition state analogs of both catalytic steps, J Biol Chem. 285 (2010) 15874-83, https://doi.org/10.1074/jbc.M109.066951. 
[59] M.M. Bradford, A rapid and sensitive method for the quantitation of microgram quantities of protein utilizing the principle of protein-dye binding, Anal. Biochem. 72 (1976) 248-254, https://doi.org/10.1006/abio.1976.9999.

[60] J.D. Siqueira, A.C.O. Menegatti, H. Terenzi, M.B. Pereira, D. Roman, E.F. Rosso, P.C. Piquini, B.A. Iglesias, D.F. Back, Synthesis, characterization and phosphatase inhibitory activity of dioxidovanadium (V) complexes with Schiff base ligands derived from pyridoxal and resorcinol, Polyhedron. 130 (2017) 184-194, https://doi.org/10.1016/j.poly.2017.04.004.

[61] A. Mascarello, A.C.O. Menegatti, A. Calcaterra, P.G.A. Martins, L.D. Chiaradia-Delatorre, I. D'Acquarica, A. Sanna, A. Logu, M. Botta, B. Botta, H. Terenzi, M. Mori, Naturally occurring Diels-Alder-type adducts from Morusnigra as potent inhibitors of Mycobacterium tuberculosis protein tyrosine phosphatase B, Eur J Med Chem. 144 (2017) 277-288, https://doi.org/10.1016/j.ejmech.2017.11.087.

[62]D. Reker, G.J.L. Bernardes, T. Rodrigues, Computational advances in combating colloidal aggregation in drug discovery, Nat. Chem. 11,(2019) 402-418, https://doi:10.1038/s41557-019-0234-9. 